\title{
Correlation Coefficient and Path Analyses of Yield and Yield Related Traits of Korean Double Haploid Rice for Germplasm Improvement in Nigeria
}

\author{
Salim Hassan Kafi ${ }^{1}$, Efisue Andrew Abiodun ${ }^{2, *}$, Olasanmi Bunmi ${ }^{3}$, Kang Kyung-Ho ${ }^{4}$ \\ ${ }^{1}$ Life and Earth Sciences Institute, (Including Health and Agriculture), Pan African University, University of Ibadan, Ibadan, Nigeria \\ ${ }^{2}$ Department of Crop \& Soil Science, University of Port Harcourt, Port Harcourt, Nigeria \\ ${ }^{3}$ Department of Agronomy, Faculty of Agriculture, University of Ibadan, Ibadan, Nigeria \\ ${ }^{4}$ Korea-Africa Food \& Agriculture Cooperation Initiative (KAFACI), Suwon, Republic of Korea
}

Email address:

andyefisue@yahoo.com (E. A. Abiodun)

${ }^{*}$ Corresponding author

\section{To cite this article:}

Salim Hassan Kafi, Efisue Andrew Abiodun, Olasanmi Bunmi, Kang Kyung-Ho. Correlation Coefficient and Path Analyses of Yield and Yield Related Traits of Korean Double Haploid Rice for Germplasm Improvement in Nigeria. American Journal of Agriculture and Forestry. Vol. 9, No. 3, 2021, pp. 114-121. doi: 10.11648/j.ajaf.20210903.13

Received: April 25, 2021; Accepted: May 10, 2021; Published: May 20, 2021

\begin{abstract}
The success of plant breeding depends on the availability of genetic variation, knowledge about desired traits, and efficient selection strategies that make it possible to exploit existing genetic resource. This study was carried out at Africa Rice Center, International Institute of Tropical Agriculture (IITA) Ibadan, Nigeria, and 239 double haploid lines from Republic of Korea were established along with one of the rice mega varieties (FARO 44) as check. The experiment was conducted using Alpha lattice design with four blocks each planted with 60 entries in two replications. Analysis of variance revealed highly significant differences $(\mathrm{P} \leq 0.001)$ among the genotypes indicating existence of variation among the genotypes. Correlation coefficient of the yield and its association traits revealed significantly positive correlation of grain yield with number of tillers, plant height, days to $50 \%$ flowering, panicle length, effective tillers, leaf area, leaf area index, fertility, biomass, panicle weight, number of grains per panicle and grain yield per plant, hence, selection for these traits can improve yield. Path coefficient analysis revealed that days to $50 \%$ flowering, leaf area index, fertility, biomass, panicle weight, number of grains per panicle and grain yield per plant exhibited positive direct effect on grain yield. Among all traits examined, panicle weight had the highest significant positive correlation and high positive direct effect. Stepwise regression showed that characters such as panicle weight, grain yield per plant, flag leaf, days to $50 \%$ flowering, effective tillers and 1000 grain weight contributed more to the total grain yield. Therefore, selections for the aforementioned characters will assist breeders in making good improvement in rice grain yield.
\end{abstract}

Keywords: Oryza, Yield Components, Double Haploid, Genotypes, Path Coefficient and Correlation

\section{Introduction}

Rice (Oryza sativa L.), one of the most important crops and second most widely cultivated cereal in the world, is a staple food for more than half of the world's population [1] The world population is expected to reach 8 billion by 2030 and rice production must be increased to meet the growing demand.[2]. With the ever-increasing rate of population, the demand for rice is increasing rapidly [3]. Hence, increase in rice production is very important in the food security and poverty alleviation [4]. The economic trait of rice is the grain yield which is influenced by complex genes and many yield contributing factors and is also highly influenced by the environmental conditions [5]. Breeding strategy in rice mainly depends upon the degree of association among characters as well as its magnitude and nature of variation. Therefore, the knowledge of association of yield components is of great importance to plant breeders as it helps in selection of crop for better quality [6]. 
Correlation and path coefficient analysis will give a better insight of association among the characters governing the grain yield. Correlation analysis provides information on the nature and extent of association between pairs of metric characters and helps in selection for crop improvement. While path coefficient analysis, allows separation of direct effects and indirect effects through other attributes by partitioning the correlations [3]. Studies on path analyses therefore provide useful information regarding the direct and indirect effects of yield component characters on grain yield and thus aid in the identification of better selection criteria for yield improvement [7]. Path coefficient analysis assists plant breeders in identifying traits that should be considered in improving a complex trait [8]

Rice grain yield, being a complex trait, depends on the various yield contributing traits like plant height, days to $50 \%$ flowering, number of productive tillers per plant, panicle length, panicle weight, number of grains per panicle and weight of 1000 grains [1]. Information on association of characters, direct and indirect effects contributed by each character towards yield will be an added advantage in aiding the selection process. Correlation and path analysis established the extent of association between yield and its components and also bring out relative importance of their direct and indirect effects, thus giving an obvious understanding of their association with grain yield and this also assist the breeders in their selection strategies to improve grain yield. [9]. Therefore, the objectives of this study were to determine the nature and degree of association between yield and its component characters and their direct and indirect effects on grain yield in rice.

\section{Materials and Methods}

\section{Experimental Location}

The experiment was conducted at experimental field of African Rice Centre at International Institute of Tropical Agriculture (IITA), Old Oyo road, Ibadan, Oyo state, Nigeria. During 2020 cropping season. IITA is located at longitude $7^{\circ} 30^{\prime} 8^{\prime \prime} \mathrm{N}$, latitude $3^{\circ} 54^{\prime} 37^{\prime} \mathrm{E}$ and at elevation $243 \mathrm{~m}$ above sea level [10]

\section{Experimental materials and design}

The experimental materials for the study consist of 239 double haploid lines from Republic of Korea were established along with one of the rice mega varieties (FARO 44) as check. The experiment was conducted using Alpha lattice design with four blocks each planted with 60 entries in two replications. Seeds of the double haploid lines were sown in the wet prepared nursery bed to raise seedlings needed for the trail, after 25 days the seedlings were transplanted to the field. A single row of size $0.2 \mathrm{~m} \times 3 \mathrm{~m}$ was used as plot at spacing of 20 $\mathrm{cm} \times 20 \mathrm{~cm}$ within and between rows and chemical fertilizer NPK (15:15:15) was applied as a basal application of $200 \mathrm{~kg} /$ ha $\left(\mathrm{N}_{2} \mathrm{P}_{2} \mathrm{O}_{5}\right.$ and $\left.\mathrm{K}_{2} \mathrm{O}\right)$. Urea was applied in two splits at the rate of $65 \mathrm{~kg} / \mathrm{ha}$ at tillering stage and the second application at the rate of $35 \mathrm{~kg} / \mathrm{ha}$ at the beginning of panicle initiation stage. Weed control was done twice using selective herbicide
Vespanil Plus (250 ml/ 20 liters of water) at early stage of crop development and before flowering.

\section{Data collection}

Data was collected at appropriate stage of the crop development. The agronomic characters were measured by randomly selected plants from each experimental unit (row). The Standard Evaluation System (SES) by International Rice Research Institute (IRRI) for Rice reference manual was used for all trait measurements except were stated otherwise [11]. The data collected were plant height, number of tillers per plant, days to $50 \%$ flowering, leaf area, leaf area index, flag leaf length, panicle fertility (\%), productive tillers per plant, panicle length, panicle weight, biomass, number of grains per panicle, 1000 grain weight, grain yield per plant and grain yield per plot ( $\mathrm{kg} / \mathrm{ha})$. Leaf area (LA) was determined using a leaf area meter (li-3100, Lincoln, NE USA). And leaf area index was calculated in meter square as described by [12]

Data Analysis

Data analysis was done using Analysis of Variance technique (ANOVA). Differences were declared statistically significant when $(\mathrm{P} \leq 0.05)$. Correlation coefficient among all the traits as well as Stepwise regression and path coefficient of direct and indirect contribution of traits on grain yield were analyzed using Statistical Analysis System [13]

\section{Results}

Agronomic Trait Evaluation of the Genotypes

Analysis of variance (ANOVA) results revealed significant differences among genotypes, block within replication and replication for all traits under consideration. Genotypes were highly significant for all traits under consideration. Significant variation was observed in block within replications for most of the traits (Table 1). These results indicate the existence of variation among the genotypes for yield and yield components under studied.

\section{Correlation Coefficient Analysis}

The correlation coefficients between grain yield and its component characters and the inter correlation among different traits that play an important role in selection of desirable genotypes (Table 2). All the traits except flag leaf ($0.018)$ and 1000 grain weight $(-0.039)$ showed different level of significant positive correlation with grain yield. Grain yield, grain yield per plant and panicle weight correlated with all the traits under consideration and number of tillers had negative but significant correlation with most of the traits under consideration (Table 2).

Days to $50 \%$ flowering and panicle length recorded positive and significant correlation with other traits except positive and nonsignificant correlation registered between days to $50 \%$ flowering and 1000 grain weight $(0.062)$ and between panicle length and effective tillers (0.033). Flag leaf showed positive and significant correlation with leaf area (0.479), leaf area index (0.479), biomass (0.314), panicle weight (0.119), number of grains per panicle (0.094) and 1000 grain weight (0.328). Positive and non-significant observed with fertility (0.052) and grain yield per plant 
(0.079) whereas negative and significant correlation noticed between flag leaf and effective tillers $(-0.111)$. (Table 2).

Effective tillers are tillers harvested at maturity which contributed to the total grain yield had positive and significant association with fertility $(0.224)$, biomass $(0.217)$, panicle weight (0.468), number of grains per panicle $(0.195)$ and grain yield per plant (0.506). Effective tillers showed negative and significant correlation with 1000 grain weight (-0.090) (Table 2).

Fertility showed positive and significant correlation with biomass $(0.123)$, panicle weight $(0.358)$, number of grains per panicle (0.411) and grain yield per plant (0.442). Biomass showed positive and significant correlation with all other grain yield components except number of tillers (Table 2).

Path Coefficient Analysis

The direct and indirect effects of different yield components as partitioned by correlation coefficient using path analysis presented in (Table 3 ).

Direct Effect

The result of direct effect as shown in (Figure 1) exhibited that leaf area index had higher value positive direct effect (1.090) followed by positive direct effect of panicle weight (0.457), grain yield per plant (0.388), days to $50 \%$ flowering (0.116), biomass (0.080), number of grains per panicle (0.037) and fertility (0.014). Positive direct effects of these traits on grain yield indicated their importance in determining this complex character and therefore, should be kept in mind while practicing selection aimed towards the improvement of grain yield. On the other hand leaf area $(-1.130)$ expressed highly negative direct effect on grain yield followed by flag leaf $(-0.122)$, effective tillers $(-0.093), 1000$ grain weight ($0.084)$, number of tillers $(-0.068)$, plant height $(-0.028)$ and panicle length (-0.014). (Figure 1, Table 3)

\section{Indirect Effect}

Number of tillers showed indirectly positive effect on grain yield through all yield components except effective tillers ($0.024)$, leaf area index $(-0.265)$ and number of grains per panicle (-0.001). The indirect effect of plant height was high positive through leaf area index $(0.455)$ and high negative through leaf area (-0.471). Days to 50\% flowering expressed indirect positive effect on grain yield through leaf area index, fertility, biomass, panicle weight, number of grains per panicle and grain yield per plant. The indirect expression of panicle length on grain yield was positive through number of tillers, days to $50 \%$ flowering, leaf area index, fertility, biomass, panicle weight, number of grains per panicle and grain yield per plant. This trait exhibited negative indirect effects on grain yield through effective tillers. Flag leaf expressed indirect positive effect on grain yield through all characters except plant height $(-0.011)$, panicle length $(-0.006)$, leaf area $(-0.540)$ and 1000 grain weight $(-0.028)$. The indirect expression of effective tillers on grain yield was negative through number of tillers (-0.017), plant height $(-0.002)$ and leaf area index (0.092). Effective tillers expressed positive indirect effect through days to $50 \%$ flowering, panicle weight, number of grains per panicle. (Figure 1, Table 3)

Leaf area showed the highest positive indirect effect on grain yield through leaf area index (1.090). Leaf area index expressed the highest negative indirect effect on grain yield through leaf area (-1.129). Fertility contributed positively indirect through days to $50 \%$ flowering, leaf area index, biomass, panicle weight, number of grains per panicle, 1000 grain weight and grain yield per plant. Biomass and panicle weight expressed positive indirect on grain yield through days to $50 \%$ flowering, leaf area index, fertility, number of grains per panicle and grain yield per plant. Panicle weight exhibited negative indirect effects through plant height, effective tillers and panicle length. The indirect effect of number of grains per panicle on grain yield were negative through plant height, panicle length, flag leaf, effective tillers and leaf area. The indirect effect of 1000 grain weight on grain yield were negative through plant height, panicle length, flag leaf, leaf area and number of grains per panicle. Grain yield per plant had positive indirect effect on grain yield through days to $50 \%$ flowering, leaf area index, fertility, biomass, panicle weight and number of grains per panicle. (Figure 1, Table 3)

Table 1. ANOVA (mean square) for different traits measured.

\begin{tabular}{|c|c|c|c|c|c|c|c|c|}
\hline SV & DF & NT & PH (cm) & D50\%F & PL (cm) & FL (cm) & ET & $\mathrm{LA}\left(\mathrm{cm}^{2}\right)$ \\
\hline REP & 1 & $146.49 * * *$ & $2.46 \mathrm{NS}$ & $206.72 * * *$ & $0.24 \mathrm{NS}$ & $2.63 \mathrm{NS}$ & $10.06 \mathrm{NS}$ & $796.69 * * *$ \\
\hline BLK (REP) & 3 & $34.35 * * *$ & $606.24 * * *$ & $42.45 * *$ & $2.54 \mathrm{NS}$ & $24.84 \mathrm{NS}$ & $15.61 * *$ & $106.20 \mathrm{NS}$ \\
\hline GEN & 236 & $17.22 * * *$ & $378.24 * * *$ & $76.23 * * *$ & $12.99 * * *$ & $90.27 * * *$ & $6.47 * * *$ & $160.92 * * *$ \\
\hline MEAN & & 8.43 & 107.68 & 59.86 & 24.71 & 30.94 & 6.44 & 32.20 \\
\hline CV (\%) & & 23.71 & 6.08 & 4.85 & 5.52 & 18.75 & 25.75 & 20.28 \\
\hline
\end{tabular}

Table 1. Continued.

\begin{tabular}{llllllll}
\hline SV & LAI $\left(\mathbf{m}^{2}\right)$ & FER $(\%)$ & BM $(\mathbf{g})$ & PW $(\mathbf{g})$ & NG/P & TGW $(\mathbf{g})$ & GY/P $(\mathbf{g})$ \\
\hline REP & $0.005 * * *$ & $1411.10 * *$ & $204.89 \mathrm{NS}$ & $602.11 * *$ & $16663.99 * * *$ & $0.35 \mathrm{NS}$ & $793.56 * * *$ \\
BLK (REP) & $0.001 \mathrm{NS}$ & $167.12 * *$ & $244.10^{*}$ & $144.00^{*}$ & $2614.12^{*}$ & $10.28^{*}$ & $256.41 * * *$ \\
GEN & $0.001 * * *$ & $50.39 * *$ & $206.47 * * *$ & $127.24 * * *$ & $1523.04 * * *$ & $20.00^{* * *}$ & $82.03 * * *$ \\
ERROR & 0.000 & 33.43 & 84.18 & 50.05 & 745.06 & 2.80 & $3002213.00 \mathrm{NS}$ \\
MEAN & 0.080 & 91.23 & 26.53 & 24.40 & 100.55 & 27.05 & 30.81 \\
CV $(\%)$ & 20.281 & 6.34 & 34.59 & 28.99 & 27.15 & 6.19 & 16.65 \\
\hline
\end{tabular}

$*, * *, * * *$ indicate significances at the $0.05,0.01$ and 0.001 levels respectively, NS indicate non-significance. NT=Number of tillers; PH=Plant height; $\mathrm{D} 50 \% \mathrm{~F}=$ Days to $50 \%$ flowering; $\mathrm{PL}=$ Panicle length; $\mathrm{FL}=$ Flag leaf; ET=Effective tillers; LA=Leaf area; LAI=Leaf area index; FER=Fertility; BM=Biomass; $\mathrm{PW}=$ Panicle weight; NG/P=Number of grains per panicle; TGW=1000 grain weight; $\mathrm{GY} / \mathrm{P}=\mathrm{Grain}$ yield per plant; YLD= yield. 
Table 2. Correlation coefficient between rice yield and its yield components.

\begin{tabular}{|c|c|c|c|c|c|c|c|c|c|c|c|c|c|c|c|}
\hline Traits & NT & PH & D50\%F & PL & FL & ET & LA & LAI & FER & BM & PW & NG/P & TGW & GY/P & YLD \\
\hline NT & - & & & & & & & & & & & & & & \\
\hline PH & $\begin{array}{l}-0.161 \\
* * *\end{array}$ & - & & & & & & & & & & & & & \\
\hline $\mathrm{D} 50 \% \mathrm{~F}$ & $0.124 * *$ & $\begin{array}{l}0.480 \\
* * *\end{array}$ & - & & & & & & & & & & & & \\
\hline PL & $-0.138 * *$ & $\begin{array}{l}0.655 \\
* * *\end{array}$ & $\begin{array}{l}0.444 \\
* * *\end{array}$ & - & & & & & & & & & & & \\
\hline FL & $\begin{array}{l}-0.228 \\
* * *\end{array}$ & $\begin{array}{l}0.388 \\
* * *\end{array}$ & $\begin{array}{l}0.236 \\
* * *\end{array}$ & $\begin{array}{l}0.384 \\
* * *\end{array}$ & - & & & & & & & & & & \\
\hline ET & $0.255 * * *$ & 0.057 & $0.147 * *$ & 0.033 & $-0.111 *$ & - & & & & & & & & & \\
\hline LA & $\begin{array}{l}-0.244 \\
* * *\end{array}$ & $\begin{array}{l}0.417 \\
* * *\end{array}$ & $\begin{array}{l}0.341 \\
* * *\end{array}$ & $\begin{array}{l}0.464 \\
* * *\end{array}$ & $\begin{array}{l}0.479 \\
* * *\end{array}$ & -0.085 & - & & & & & & & & \\
\hline LAI & $\begin{array}{l}-0.244 \\
* * *\end{array}$ & $\begin{array}{l}0.417 \\
* * *\end{array}$ & $\begin{array}{l}0.341 \\
* * *\end{array}$ & $\begin{array}{l}0.464 \\
* * *\end{array}$ & $\begin{array}{l}0.479 \\
* * *\end{array}$ & -0.085 & $\begin{array}{l}0.999 \\
* * *\end{array}$ & - & & & & & & & \\
\hline FER & $0.095 *$ & $\begin{array}{l}0.200 \\
* * *\end{array}$ & $\begin{array}{l}0.309 \\
* * *\end{array}$ & $\begin{array}{l}0.234 \\
* * *\end{array}$ & 0.052 & $\begin{array}{l}0.224 \\
* * *\end{array}$ & 0.042 & 0.042 & - & & & & & & \\
\hline BM & 0.084 & $\begin{array}{l}0.539 \\
* * *\end{array}$ & $\begin{array}{l}0.344 \\
* * *\end{array}$ & $\begin{array}{l}0.418 \\
* * *\end{array}$ & $\begin{array}{l}0.314 \\
* * *\end{array}$ & $\begin{array}{l}0.217 \\
* * *\end{array}$ & $\begin{array}{l}0.432 \\
* * *\end{array}$ & $\begin{array}{l}0.432 \\
* * *\end{array}$ & $0.123 * *$ & - & & & & & \\
\hline PW & $0.098 *$ & $\begin{array}{l}0.385 \\
* * *\end{array}$ & $\begin{array}{l}0.332 \\
* * *\end{array}$ & $\begin{array}{l}0.366 \\
* * *\end{array}$ & $0.119 * *$ & $\begin{array}{l}0.468 \\
* * *\end{array}$ & $\begin{array}{l}0.255 \\
* * *\end{array}$ & $\begin{array}{l}0.255 \\
* * *\end{array}$ & $\begin{array}{l}0.358 \\
* * *\end{array}$ & $\begin{array}{l}0.606 \\
* * *\end{array}$ & - & & & & \\
\hline $\mathrm{NG} / \mathrm{P}$ & -0.032 & $\begin{array}{l}0.285 \\
* * *\end{array}$ & $\begin{array}{l}0.327 \\
* * *\end{array}$ & $\begin{array}{l}0.288 \\
* * *\end{array}$ & $0.094 *$ & $\begin{array}{l}0.195 \\
* * *\end{array}$ & $\begin{array}{l}0.179 \\
* * *\end{array}$ & $\begin{array}{l}0.179 \\
* * *\end{array}$ & $\begin{array}{l}0.411 \\
* * *\end{array}$ & $\begin{array}{l}0.169 \\
* * *\end{array}$ & $\begin{array}{l}0.499 \\
* * *\end{array}$ & - & & & \\
\hline TGW & $\begin{array}{l}-0.229 \\
* * *\end{array}$ & $\begin{array}{l}0.292 \\
* * *\end{array}$ & 0.062 & $\begin{array}{l}0.245 \\
* * *\end{array}$ & $\begin{array}{l}0.328 \\
* * *\end{array}$ & $-0.090 *$ & $\begin{array}{l}0.264 \\
* * *\end{array}$ & $\begin{array}{l}0.264 \\
* * *\end{array}$ & -0.011 & $\begin{array}{l}0.208 \\
* * *\end{array}$ & 0.061 & -0.037 & - & & \\
\hline GY/P & $0.170 * * *$ & $\begin{array}{l}0.344 \\
* * *\end{array}$ & $\begin{array}{l}0.385 \\
* * *\end{array}$ & $\begin{array}{l}0.315 \\
* * *\end{array}$ & 0.079 & $\begin{array}{l}0.506 \\
* * *\end{array}$ & $0.121 * *$ & $0.121 * *$ & $\begin{array}{l}0.442 \\
* * *\end{array}$ & $\begin{array}{l}0.328 \\
* * *\end{array}$ & $\begin{array}{l}0.626 \\
* * *\end{array}$ & $\begin{array}{l}0.513 \\
* * *\end{array}$ & 0.086 & - & \\
\hline YLD & $0.104 *$ & $\begin{array}{l}0.301 \\
* * *\end{array}$ & $\begin{array}{l}0.372 \\
* * *\end{array}$ & $\begin{array}{l}0.276 \\
* * *\end{array}$ & -0.018 & $\begin{array}{l}0.368 \\
* * *\end{array}$ & $0.130 * *$ & $0.130 * *$ & $\begin{array}{l}0.367 \\
* * *\end{array}$ & $\begin{array}{l}0.413 \\
* * *\end{array}$ & $\begin{array}{l}0.715 \\
* * *\end{array}$ & $\begin{array}{l}0.477 \\
* * *\end{array}$ & -0.039 & $\begin{array}{l}0.675 \\
* * *\end{array}$ & - \\
\hline
\end{tabular}

* $\mathrm{P}<0.05$, ** $\mathrm{P}<0.01$, *** $\mathrm{P}<0.001 \mathrm{NT}=$ Number of tillers; $\mathrm{PH}=\mathrm{Plant}$ height; $\mathrm{D} 50 \% \mathrm{~F}=$ Days to $50 \%$ flowering; $\mathrm{PL}=\mathrm{Panicle} \mathrm{length}$; $\mathrm{FL}=\mathrm{Flag}$ leaf; $\mathrm{ET}=$ Effective tillers; LA=Leaf area; LAI=Leaf area index; FER=Fertility; $\mathrm{BM}=$ Biomass; $\mathrm{PW}=\mathrm{Panicle}$ weight; NG/P=Number of grains per panicle; $\mathrm{TGW}=1000$ grain weight; $\mathrm{GY} / \mathrm{P}=$ Grain yield per plant; $\mathrm{YLD}=$ yield

Table 3. Path coefficient analysis of yield and yield contributing characters of rice genotypes.

\begin{tabular}{llllllllllllllll}
\hline Trails & NT & PH & DF & PL & FL & ET & LA & LAI & FER & BM & PW & NG/P & TGW & GY/P & YLD \\
\hline NT & -0.068 & 0.005 & 0.014 & 0.002 & 0.028 & -0.024 & 0.275 & -0.265 & 0.001 & 0.007 & 0.045 & -0.001 & 0.019 & 0.066 & 0.104 \\
PH & 0.011 & -0.028 & 0.056 & -0.009 & -0.047 & -0.005 & -0.471 & 0.455 & 0.003 & 0.043 & 0.176 & 0.011 & -0.025 & 0.134 & 0.301 \\
DF & -0.008 & -0.014 & 0.116 & -0.006 & -0.029 & -0.014 & -0.386 & 0.372 & 0.004 & 0.028 & 0.152 & 0.012 & -0.005 & 0.149 & 0.372 \\
PL & 0.009 & -0.019 & 0.052 & -0.014 & -0.047 & -0.003 & -0.524 & 0.506 & 0.003 & 0.034 & 0.167 & 0.011 & -0.021 & 0.122 & 0.276 \\
FL & 0.015 & -0.011 & 0.027 & -0.006 & -0.122 & 0.010 & -0.540 & 0.521 & 0.001 & 0.025 & 0.054 & 0.004 & -0.028 & 0.031 & -0.018 \\
ET & -0.017 & -0.002 & 0.017 & 0.000 & 0.013 & -0.093 & 0.096 & -0.092 & 0.003 & 0.017 & 0.214 & 0.007 & 0.008 & 0.196 & 0.368 \\
LA & 0.016 & -0.012 & 0.040 & -0.007 & -0.058 & 0.008 & -1.130 & 1.090 & 0.001 & 0.035 & 0.116 & 0.007 & -0.022 & 0.047 & 0.130 \\
LAI & 0.016 & -0.012 & 0.040 & -0.007 & -0.058 & 0.008 & -1.129 & 1.090 & 0.001 & 0.035 & 0.116 & 0.007 & -0.022 & 0.047 & 0.130 \\
FER & -0.006 & -0.006 & 0.036 & -0.003 & -0.006 & -0.021 & -0.047 & 0.045 & 0.014 & 0.010 & 0.164 & 0.015 & 0.001 & 0.172 & 0.367 \\
BM & -0.006 & -0.015 & 0.040 & -0.006 & -0.038 & -0.020 & -0.488 & 0.471 & 0.002 & 0.080 & 0.277 & 0.006 & -0.017 & 0.127 & 0.413 \\
PW & -0.007 & -0.011 & 0.039 & -0.005 & -0.014 & -0.043 & -0.288 & 0.278 & 0.005 & 0.049 & 0.457 & 0.018 & -0.005 & 0.243 & 0.715 \\
NG/P & 0.002 & -0.008 & 0.038 & -0.004 & -0.011 & -0.018 & -0.202 & 0.194 & 0.006 & 0.014 & 0.228 & 0.037 & 0.003 & 0.199 & 0.477 \\
TGW & 0.015 & -0.008 & 0.007 & -0.004 & -0.040 & 0.008 & -0.298 & 0.288 & 0.000 & 0.017 & 0.028 & -0.001 & -0.084 & 0.033 & -0.039 \\
GY/P & -0.011 & -0.010 & 0.045 & -0.005 & -0.010 & -0.047 & -0.136 & 0.131 & 0.006 & 0.026 & 0.286 & 0.019 & -0.007 & 0.388 & 0.675 \\
\hline
\end{tabular}

PU Residual effect $=0.605$. Coefficient of determination $=0.634$. The direct effects are in bold on the diagonal

$\mathrm{NT}=$ Number of tillers; $\mathrm{PH}=\mathrm{Plant}$ height; $\mathrm{D} 50 \% \mathrm{~F}=$ Days to $50 \%$ flowering; $\mathrm{PL}=$ Panicle length; FL=Flag leaf; ET=Effective tillers; LA=Leaf area; LAI=Leaf area index; FER=Fertility; $\mathrm{BM}=$ Biomass; $\mathrm{PW}=\mathrm{Panicle}$ weight; $\mathrm{NG} / \mathrm{P}=$ Number of grains per panicle; $\mathrm{TGW}=1000$ grain weight; $\mathrm{GY} / \mathrm{P}=\mathrm{Grain}$ yield per plant; $\mathrm{YLD}=$ yield

Stepwise Regression Analysis

Stepwise regression analysis for variables (Table 4) had highly significant $(\mathrm{P}<0.001)$ for panicle weight, grain yield per plant, flag leaf and days to $50 \%$ flowering and significant $(\mathrm{P}<0.05)$ for effective tillers and 1000 grain weight. 
Table 4. Stepwise regression of more contributed traits on grain yield.

\begin{tabular}{lllllll}
\hline Step & Variable & Partial R-Square & Model R-Square & C(p) & F Value & Significance \\
\hline 1 & PW & 0.5107 & 0.5107 & 144.801 & 498.99 \\
2 & GYP & 0.0853 & 0.5961 & 38.537 & 100.76 \\
3 & FL & 0.0102 & 0.6062 & 27.6186 & 12.31 \\
4 & D50\%F & 0.0103 & 0.6165 & 16.6075 & 12.7 & $* * *$ \\
5 & ET & 0.0054 & 0.6219 & 11.8167 & 6.71 & $* *$ \\
6 & TGW & 0.0056 & 0.6274 & 6.7311 & $* 09$ \\
\hline
\end{tabular}

$*, * *, * * *$ indicate significances at the $0.05,0.01$ and 0.001 levels respectively.

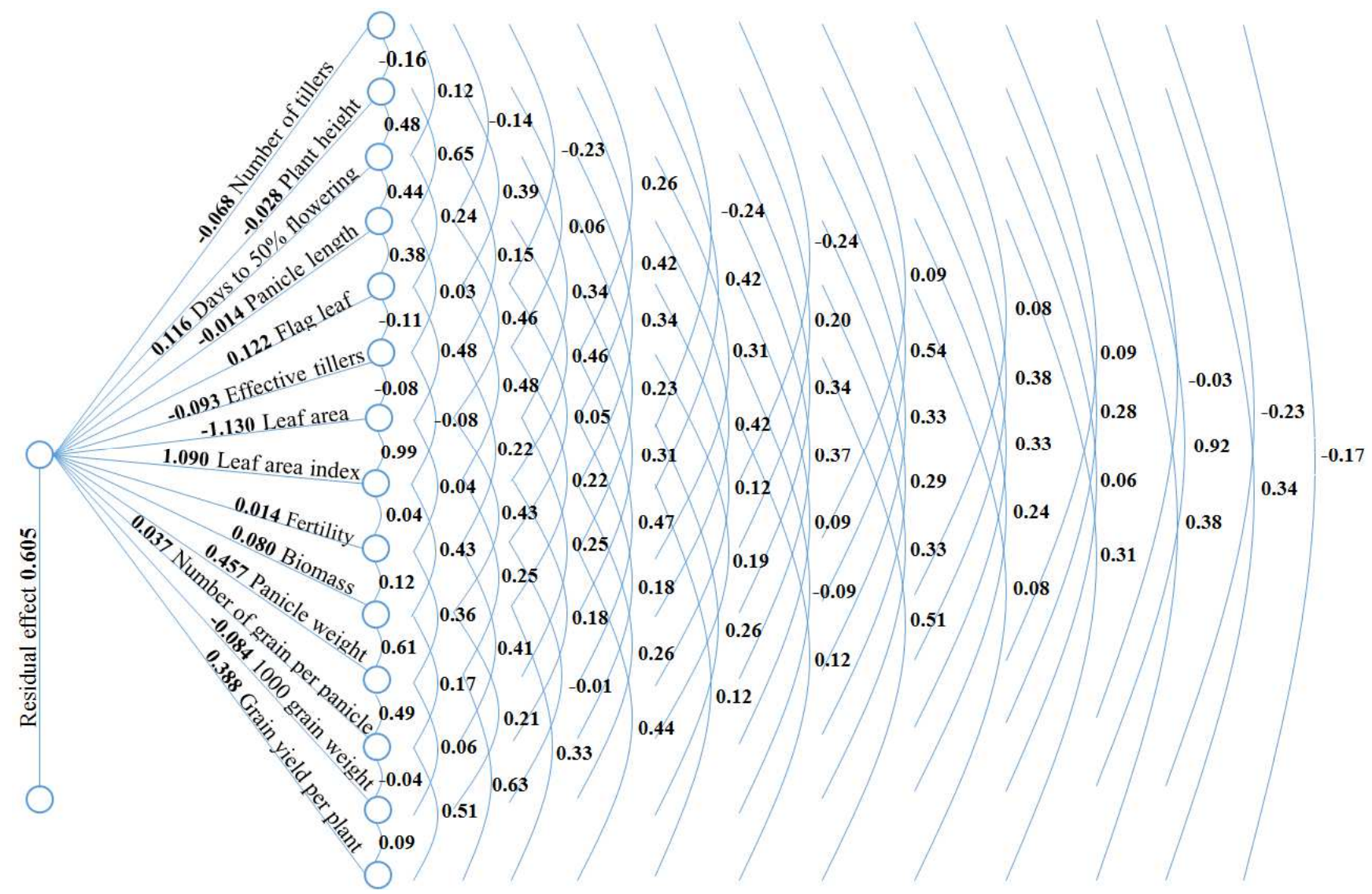

Figure 1. Path diagram of yield and its contributing traits.

\section{Discussion}

Correlation Coefficient Analysis

Good knowledge of germplasm diversity and genetic relationships among breeding materials could be a valuable tool for crop improvement. Genetic diversity determines the inherent potential of heterosis and frequency of desirable recombinants that could be present in advanced generations [14]. A large number of anther-culture genotypes and the improved variety used in this study showed high genetic diversity and genetic variation among the genotypes. The presence of high genetic variability could be due to diverse materials used in this study as well as environmental influence, this corroborate the report and similar genetic variations have been reported who observed significant genetic differences for all characters studied in different rice genotypes $[15,16,17,18]$.

The observed positive and significant correlation of grain yield with rice yield components have also been reported [8, 12]. Effective tiller is the harvested tillers at maturity of the rice crop, the higher the number the higher the total grain yield. The high positive correlation of grain yield and effective tillers indicates an effective index in increasing the total grain yield and genotypes exhibiting this trait are potential for germplasm improvement similar reports on copper and iron compounds on rice [19, 20]. Panicle weight showed positive and significant correlation with number of grains per panicle similar results were reported [21, 22]. Therefore, priority should also be given to those traits that had high positive correlation with grain yield such as grain yield per plant and panicle weight while making selection for yield improvement. Potential double haploid lines have been identified for rice improvement in Nigeria.

\section{Path Coefficient Analysis}

Direct Effect

Path coefficient analysis provides an effective means of determining the magnitude of each contributing trait to the 
grain yield either directly or indirectly. Breeding new variety with yield potential is one of the main objectives of plant breeders and there are several yield components controlling the yield potential directly or indirectly. Leaf area index is responsible for photosynthesis efficiency and it plays an important role in grain yield production [23]. High positive direct effect of leaf area index was recorded similar report this indicates that leaf area index is an important criterion for increasing rice grain yield [6].

Panicle weight is one of the yield components, panicles has to be long to accommodate more grains, which translate to higher panicle weight. Panicle weight had high positive direct effect on grain yield similar reports [24, 25]. Therefore, genotypes with high panicle weight could possess high yielding ability and good for crop improvement. Grain yield per plant is one of the determinants of high grain yield. Results showed that grain yield per plant had high positive direct effect on yield.

Apart from genetic influence, other factors also affect days to $50 \%$ flowering such as plant spacing, irrigation and weeding induce early flowering. Days to $50 \%$ flowering influences maturity period and showed positive direct effect on yield, the result corroborate the reports [26, 27]. Biomass accumulation is important for grain yield formation and improvement of rice yield could results in the increase of biomass. Biomass showed positive direct effect on yield [28].

Number of grains per panicle is important yield contributing trait that require long panicle to accommodate more grains. Number of grains per panicle found to be direct effect and positive on yield this result corroborate $[29,30,31]$

Some traits expressed negative direct effects on yield such as leaf area, flag leaf, effective tillers, 1000 grain weight, number of tillers, plant height and panicle length (Table 3) suggesting that these traits are not reliable in the selection process for grain yield. Direct negative effects of plant height on grain yield were also reported [5, 25, 30, 31 32] for plant height, but positive direct effect of plant height on grain yield which is contradictory with the present study was reported [26, 33]

\section{Indirect Effect}

Path coefficient also indicates traits that have indirect effects with grain yield. It could be suggested that breeders should also pay more emphasis on those traits with positive indirect effects on grain yield. Plant height showed positive indirect effect through fertility where the result in conformity with [34] and as well, plant height expressed negative indirect effect through panicle length corroborate the report [35]. The results showed that days to $50 \%$ flowering had indirect positive effect on grain yield through panicle weight, panicle weight and number of grains per panicle similar results were reported by $[25,36]$. Panicle length showed positive indirect effect on grain yield through days to $50 \%$ flowering, panicle weight and number of grains per panicle.

Effective tillers expressed positive indirect effect through days to $50 \%$ flowering, panicle weight, number of grains per panicle similar results were reported [36]. Panicle weight exhibited negative indirect effects through plant height and indirect effect of number of grains per panicle on grain yield were negative through panicle length and effective tillers, the negative indirect effects may not be very beneficial in selection for crop improvement and similar reports [3, 35 37]. The high residual effect $(0.605)$ in this study indicated that beside the characters studied, there are some other attributes for grain yield. This result is in concurrence with findings reported $[38,39]$. Hence, considering the nature and magnitude of character association and their direct and indirect effects, it can be deduced that simultaneous improvement of grain yield is possible through manifestation of leaf area index, panicle weight, grain yield per plant and days to $50 \%$ flowering. High direct effects of these traits therefore, appeared to be the main factor for their strong association with grain yield. Hence, these traits should be considered as important selection criteria in all rice improvement programme and direct selection for these traits is recommended for yield improvement.

\section{Stepwise Regression Analysis}

Stepwise regression is a semi-automated process of building a model by successively adding or removing variables based on the t-statistics of their estimated coefficients [40]. Based on the stepwise regression analysis for variables, indicates highly significant $(\mathrm{P}<0.001)$ for panicle weight, grain yield per plant, flag leaf and days to $50 \%$ flowering and significant $(\mathrm{P}<0.05)$ for effective tillers and 1000 grain weight. This showed that these characters had contributed highly to grain yield and could be used as criteria for selection in rice breeding programme. These results are also in agreement with the findings [41, 42]. Panicle weight had the highest R-Square and explained $51 \%$ of the total variations relative to grain yield. Also, this trait had strong positive direct effect $(0.457)$ and the highest correlation coefficient $(0.715)$ with grain yield. These results showed that regression analysis agreed with path analysis in this study.

\section{Conclusion}

The study showed the existence of a considerable level of diversity among the rice double haploid genotypes, which could be used for rice improvement in Nigeria. Correlation coefficient analysis revealed that grain yield had high positive and significant correlation $(\mathrm{P} \leq 0.001)$ with panicle weight, grain yield per plant, number of grains per panicle and biomass. Path coefficients analysis revealed the importance of panicle weight, grain yield per plant, number of grains per panicle and biomass as selection criteria for effective grain yield improvement. Path analysis showed that leaf area index, panicle weight, grain yield per plant and days to $50 \%$ flowering had high direct effects on grain yield. Among these characters, panicle weight had very significant positive correlation and high positive direct effects. Hence, selection for this character could accelerate improvement in grain yield and yield components. Stepwise regression showed the magnitude of the characters panicle weight, grain yield per plant, flag leaf, days to $50 \%$ flowering, effective 
tillers and 1000 grain weight as more contributed factors to grain yield. Therefore, selection base on these characters will be more effective in rice breeding and for germplasm improvement in Nigeria.

\section{Acknowledgements}

Authors wish to express their gratitude to KAFAC of RDA Korea for providing the genetic materials (anther culture derived) used for this study under the project KAR20190112. Gratitude to Pan African University, Life and Earth Science Institute (PAULESI) for granting Salim Hassan Kafi scholarship for this study.

\section{References}

[1] Sreedhar, S. and Reddy, U. R. 2019. Association Studies for Yield and Its Traits in Rice (Oryza sativa L.) Genotypes. International Journal of Current Microbiology and Applied Sciences $\quad 8 . \quad 1: \quad 2337-2342$ https://doi.org/10.20546/ijcmas.2019.801.245

[2] Akinwale, M. G., Gregorio, G., Nwilene, F., Akinyele, B. O., Ogunbayo, S. A. and Odiyi, A. C. 2011. Heritability and correlation coefficient analysis for yield and its components in rice (Oryza sativa L.). African Journal of Plant Science 5. 3: 207-212. Retrieved

http://www.academicjournals.org/ajps

[3] Kiranmayee, B., Damodar, C. R., Kempa, R. K. B. and Balaram, M. 2018. A Study on Correlation and Path Coefficient Analysis for Yield and Yield Contributing Traits in Maintainer (B lines) Lines of Hybrid Rice (Oryza sativa L.). International Journal of Current Microbiology and Applied Sciences $\quad 7.6$ 6: 2918-2929. https://doi.org/10.20546/ijcmas.2018.706.343

[4] Bornare, S. S., Mittra, S. K. and Mehta A. K. 2014. Genetic Variability, Correlation and Path Analysis of Floral, Yield and its Component Traits in CMS and Restorer Lines of Rice (Oryza sativa L.). Bangladesh J 43. 1: 45-52.

[5] Ratna, M., Begum, S., Husna, A., Dey, S. and Hossain, M. S. 2015. Correlation and path coefficients analyses in basmati rice. Bangladesh J. Agril. Res. 40. 1: 153-161.

[6] Vengatesh, M., and Govindarasu, R. 2018. Studies on correlation and path analysis in rice (Oryza sativa L.) genotypes. Electronic Journal of Plant Breeding 9. 4: 15701576. https://doi.org/10.5958/0975-928X.2018.00195.3

[7] Kishore, S. N., Srinivas, T., Nagabhushanam, U., Pallavi, M., and Sameera, S. 2015. Genetic Variability, Correlation and Path Analysis for Yield and Yield Components in Promising Rice (Oryza sativa L.) Genotypes. SAARC J. Agri 13. 1: 99-108.

[8] Shobhana, V. G., Kumar, R. N., Ashokkumar, K., Karthikeyan, A., Kumar, N., Sheeba, A. and Vivekanandan, P. 2018. Correspondence VG Shobhana Correlation and path analysis in new plant type and indica lines of rice. $~ 3153 \sim$ International Journal of Chemical Studies 6. 3: 3153-3157

[9] Babu, V. R., Shreya, K., Dangi, K. S., Usharani, G. and Shankar, A. S. 2012. Correlation and Path Analysis Studies in Popular Rice Hybrids of India. International Journal of Scientific and Research Publications 2. 3: 1-5.
[10] Ariyo, O. C., Okojie, L. O., and Ariyo, M. O. 2018. Villagers Willingness to Pay for Forest Conservation in Ibadan, Oyo State, Nigeria. Asian Journal of Agricultural Extension, Economics \& Sociology 23. 4: 1-14. https://doi.org/10.9734/AJAEES/2018/40142

[11] SES-IRRI. 2002. "Standard Evaluation System for Rice." Find out how the qualities of rice are evaluated and scored in authoritative sourcebook.

[12] Andrew Abiodun Efisue, Cynthia Chimezie Dike (2020a). Screening Rice (Oryza sativa. L.) for Salinity Tolerance for Yield and Yield Components in Saline Stressed Environment. American Journal of Agriculture and Forestry. Vol. 8, No. 1, 2020, pp. 15-21. doi: 10.11648/j.ajaf.20200801.13.

[13] SAS (computer program). Version 9.4. Cary, NC: SAS Institute Inc; 2018.

[14] Ovung, C. Y., Lal, G. M., and Rai, P. K. 2012. Studies on genetic diversity in Rice (Oryza sativa L.). Journal of Agricultural Technology 8. 3: 1059-1065.

[15] Zakayo, A. M. 2013. Variation and Interrelationships among Yield and Yield Components in Lowland Rice Genotypes (Oryza Sativa L.) in Mwanza Region. Journal of Petrology 369. 1: 1689-1699.

[16] Nirmaladevi, G., Padmavathi, G., Kota, S., and Babu, V. R. 2015. Genetic Variability, Heritability and Correlation Coefficients of Grain Quality Characters in Rice (Oryza sativa L.). SABRAO Journal of Breeding and Genetics 47. 4: 424- 433.

[17] Augustina, U. A., Iwunor, O. P. and Ijeoma, O. R. 2013. Heritability and character correlation among some rice genotypes for yield and yield components. J. Plant Breed. Genet. 1: 73-84.

[18] Konate, A. K., Zongo, A., Kam, H., Sanni, A. and Audebert, A. 2016. Genetic variability and correlation analysis of rice (Oryza sativa L.) inbred lines based on agro-morphological traits. Afr. J. Agric. Res. 11:3340-3346.

[19] Efisue Andrew, Ogunwole Dorcas, Olaoye Olawale (2020b). Effects of Copper $(\mathrm{Cu})$ on Yield Components and Associated Traits in Segregating Populations of Lowland Rice (O. sativa L.). International Journal of Genetics and Genomics. Vol. 8, No. 2, 2020, pp. 85-93. doi: 10.11648/j.ijgg.20200802.15.

[20] Efisue Andrew, Ogunwole Dorcas, Olaoye Olawale (2020c). Effects of Iron on the Productivity of Lowland Rice ( $O$. sativa L.) in Segregating Populations. American Journal of Agriculture and Forestry. Vol. 8, No. 4, 2020, pp. 91-99. doi: 10.11648/j.ajaf.20200804.11

[21] Nandeshwar, B. C., Pal, S., Senapati, B. K. and De, D. K. 2010. Genetic variability and character association among biometrical traits in F2 generation of some Rice crosses. Electronic Journal of Plant Breeding. 1. 4: 758-763.

[22] Ranawake, A. L. and Amarasinghe, U. G. S. 2014. Relationship of yield and yield related traits of some traditional rice cultivars in Sri Lanka as described by correlation analysis. Journal of Scientific Research \& Reports. 3. 18: $2395-2403$.

[23] Efisue, A. A., Umunna, B. C., and Orluchukwu, J. A. 2014d. Effects of yield components on yield potential of some lowland rice (Oyza sativa L.) in coastal region of Southern Nigeria. Journal of Plant Breeding and Crop Science 6. 9: 119-12. https://doi.org/10.5897/JPBCS2014.0449 
[24] Cyprien and Kumar. 2011. Correlation and Path Coefficient Analysis of rice cultivars data. Journal of Reliability and Statistical Studies. 4. 2: 119-131.

[25] Srijan, A., Sudheer Kumar, S., Damodar Raju, Ch., Jagadeeshwar, R. 2016. Character association and path coefficient analysis for grain yield of parents and hybrids in rice (Oryza sativa L.). Journal of Applied and Natural Science. 8. 1: 167-172.

[26] Bhadru, D., Reddy, D. L. and Ramesha, M. S. 2011. Correlation and path coefficient analysis of yield and yield contributing traits in rice hybrids and their parental lines. Electronic Journal of Plant Breeding 2. 1: 112-116.

[27] Chandra, B. S., Reddy, T. D., Ansari, N. A. and Kumar, S. S. 2009. Correlation and path coefficient analysis for yield and yield components in rice (Oryza sativa L.). Agric. Sci. Digest 29. 1: 45-47.

[28] Jember, M. B. Firew M. Alemayehu, A. 2018. Correlation Coefficient and Path Analysis among Yield and Yield Related Traits in Upland Rice (Oryza sativa L. and Oryza glaberrima Steud) Genotypes in Northwestern Ethiopia. International Journal of Plant Breeding and Crop Science 5.3: 429-436. https://doi.org/10.15580/gjpbcs.2018.3.092818140

[29] Eswara Reddy, G., Suresh, B. G. and Sravan, T. 2013. Correlation and path analysis for yield and yield attributes in rice (Oryza sativa L.) genotypes. International Journal of Plant Sciences. 8.2: 391-394.

[30] Naseem, I., Khan, A. S. and Akhter, M. 2014. Correlation and path coefficient of some yield related traits in rice (Oryza sativa L.). International Journal of Scientific and Research Publications. 4.4: 1-5.

[31] Binod, P. B., Niranjan, A., Sharma, S. N. and Surendra, P. 2016. Variability, Correlation and Path Coefficient Analysis of Rice (Oryza sativa L.). International Journal of Scientific \& Engineering Research. 7. 8.

[32] Akhtar, N., Nazir, M. F., Rabnawaz, A., Mahmood, T., Safdar, M. E., Asif, M. and Rehman, A. 2011. Estimation of heritability, correlation and path coefficient analysis in fine grain rice (Oryza sativa L.). J. Anim. Plant Sci. 21: 660-664.

[33] Rajendra, K. P., Radha Krishna, K. V., Bhave, M. H. and Subba Rao, L. V. 2015. Correlation and path coefficient analysis for yield and yield component traits in boro rice
(Oryza sativa L.). International J. of Tropical Agriculture 33. 2: 735-740.

[34] Kumari, M., Suresh, B. G., and Jyothi, T. 2015. Evaluation of Rice (Oryza sativa L.) Germplasm for Yield. The Ecosean an International Quarterly Journal of Environmental Sciences 9. 3\&4: 867-872.

[35] Patel, J. R., Saiyad, M. R., Prajapati, K. N., Patel, R. A and Bhavani, R. T. 2014. Genetic variability and character association studies in rainfed upland rice (Oryza sativa L.). Electronic Journal of Plant Breeding. 5. 3: 531-537.

[36] Rajendra Prasad, K., Radha Krishna, K. V., Sudheer Kumar, S., Senguttuvel, P., and Subba Rao, L. V. 2017. Character Association and Path Analysis studies for Quantitative Traits in Hybrid Rice (Oryza sativa L.). International Journal of Pure and Applied Bioscience. 5.4: 1513-1518.

[37] Awaneet, K. and Senapati, B. K. 2013. Genetic parameters and association studies for important quantitative traits in advanced lines of Sambamahsuri derivatives. Journal of Crop and Weed. 9.1: 156-163.

[38] Sudeepthi, K., Jyothula, D. P. B., Suneetha, Y., and Rao, V. S. 2017. Character Association and Path Analysis Studies for Yield and its Component Characters in Rice (Oryza sativa L.). International Journal of Current Microbiology and Applied Sciences 6.11: 2360-2367.

[39] Selvaraj, I. C., Nagarajan, P., Thiyagarajan, K., Bharathi, M. and Rabindran, R. S. 2011. Genetic parameters of variability, correlation and path coefficient studies for grain yield and other yield Attributes among rice blast disease resistant genotypes of rice (Oryza sativa L.). African Journal of Biotechnology 10.17: 3322-3334.

[40] Leilah, A. A. and Al-Khateeb, S. A. 2005. Statistical analysis of wheat yield under drought conditions. Journal of Arid Environment 61: 483-496.

[41] Sharifi, P., Dehghani, H., Mumeni, A. and Moghaddam, M. 2013. Genetic relations of some of rice agronomic traits with grain yield using multivariate statistical methods. Iranian Journal of Field Crop Science 44.1: 179-169.

[42] Li, G., Zhang. J., Yang, C., Song, Y., Zheng, C., Wang, S., Liu, Z. and Ding. Y. 2014. Optimal yield-related attributes of irrigated rice for high yield potential based on path analysis and stability analysis. The Crop Journal 2: 235-243. 